\title{
Effects of Maruca vitrata multi-nucleopolyhedrovirus and neem oil, Azadirachta indica Juss on the eggs of the cowpea pod borer, Maruca vitrata Fabricius (Lepidoptera: Crambidae)
}

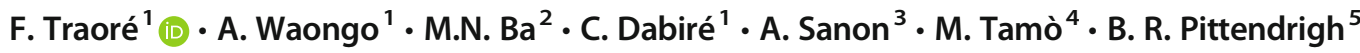 \\ Received: 9 April 2019 / Accepted: 15 October 2019 \\ (C) The Author(s) 2019, corrected publication 2021
}

\begin{abstract}
Cowpea, Vigna unguiculata (L.) Walp., is the most cultivated and consumed legume in West Africa and is typically attacked by several insect pests, including Maruca vitrata, leading to reduced yields. This study assessed under laboratory conditions the efficacy of neem oil and M. vitrata multi-nucleopolyhedrovirus (MaviMNPV) against M. vitrata eggs as alternatives to second generation pesticides. Hatching and mortality rates after biopesticide application of neem oil, MaviMNPV, and the two in combination reduced the egg viability by $89 \%, 84 \%$ and $91 \%$, respectively. Moreover, the combination of MaviMNPV and neem oil induced $100 \%$ mortality among the hatched larvae, compared to $60 \%$ and $100 \%$ alone, respectively. Implications for using these biopesticides are discussed within an integrated pest management (IPM) context.
\end{abstract}

Keywords Baculoviruses $\cdot$ Biopesticides $\cdot$ Cowpea pod borer $\cdot$ Eggs $\cdot$ Maruca vitrata multi-nucleopolyhedrovirus $\cdot$ Neem oil

\section{Introduction}

Cowpea, Vigna unguiculata L. (Walp.) is the most important edible grain legume in West Africa. The typical cowpea yield in the field is often lowered by several insect pests, including the legume pod borer Maruca vitrata, whose populations attain damaging levels in southern Burkina Faso where the rainfall is between 900 and $1200 \mathrm{~mm}$ (Ba et al. 2009). Larvae of M. vitrata feed predominantly on reproductive organs such as the flowers and developing pods (Traoré et al. 2013). Chemical insecticides are effective in controlling M. vitrata (Amatobi 1995; Atachi and

F. Traoré

foussnitraore@gmail.com

1 Institut de l'Environnement et de Recherches Agricoles, Ouagadougou Burkina Faso

2 International Crops Research Institute for the Semi-Arid Tropics, Niamey Niger

3 Laboratoire d'Entomologie Fondamentale et Appliquée, UFR/SVT, Université Ouaga I Pr Joseph KI-ZERBO, Ouagadougou Burkina Faso

4 International Institute of Tropical Agriculture, Cotonou Bénin

5 Department of Entomology, Michigan State University, East Lansing MI USA
Sourokou 1989) but they are not widely applied because of the associated high cost, the lack of good quality products, and the challenges to safe-use practices especially for smallholder lowliterate farmers (Pimentel et al. 1992; Tan et al. 1996) Therefore, it becomes imperative to provide cowpea farmers with alternative control methods, as part of an integrated pest management (IPM) system (Tamò et al. 2003).

Biopesticides constitute one alternative solution to the use of chemical insecticides and have the advantage of being biodegradable (Martinez 2002) with low, or no, toxicity to humans and animals (Valle Pinheiro and Dias Quintela 2010). Recent efforts have focused on the efficacy of a combination of biopesticides against $M$. vitrata larvae (Sokame et al. 2015). Among the biopesticides successfully assessed were neem oil (Azadirachta indica Juss) and the $M$. vitrata multi-nucleopolyhedrovirus (MaviMNPV). Neem-based preparations have been reported to be effective for controlling M. vitrata (Jackai et al. 1992; Jackai and Oyediran 1991; Tanzubil 2000), but the effectiveness of neem has been variable from year to year (Bottenberg and Singh 1996) mainly because of the lack of a standardized product. A commercialized standardized neem oil is now available in Benin and has been successfully tested against $M$. vitrata in Benin and Burkina Faso (Drabo 2014; Ouédraogo 2013; Sokame et al. 2015). 
MaviMNPV is a baculovirus. It was first isolated in Taiwan from infected larvae of $M$. vitrata on yard-long beans and found to be highly effective against $M$. vitrata larvae (Lee et al. 2007). The virus was introduced into the laboratories of the International Institute of Tropical Agriculture (IITA) in Benin, where its efficacy was confirmed, achieving over $95 \% \mathrm{M}$. vitrata larval mortality (Tamò et al. 2012). Moreover, field trials in Benin, Burkina Faso, and Niger indicated that the viral biopesticide could be as effective as conventional insecticides in controlling M. vitrata (Tamò et al. 2012).

Nucleopolyhedroviruses such as Spodoptera litura NPV and MaviNPV combined with neem have been successfully assessed in the field against the larvae of S. litura (Nathan and Kalaivani 2006) and M. vitrata (Drabo 2014; Kadri et al. 2013), respectively. The combination of MaviMNPV with neem and Jatropha curcas was effective in controlling $M$. vitrata larvae (Sokame et al. 2015). However, to our knowledge, no studies have been reported on the use of these biopesticides against $M$. vitrata eggs. Were such effectiveness demonstrated, they then might provide a basis for early, on-farm spraying to rapidly control pest populations. The current study was undertaken, therefore, to assess the effect of a combination of neem oil and the MaviMNPV biopesticide against the eggs of $M$. vitrata under laboratory conditions.

\section{Materials and methods}

\section{M. vitrata culturing}

Eggs of $M$. vitrata used in the bioassays were obtained from a mass rearing facility at the INERA entomology laboratory at Kamboinsé in Ouagadougou, Burkina Faso $\left(12^{\circ} 28^{\prime} \mathrm{N}\right.$, $\left.32^{\circ} 1^{\prime} \mathrm{W}\right)$. The insect colony was established from wild M. vitrata moths collected from light traps in August 2014. Adults were kept in cups for oviposition in a room maintained at $24{ }^{\circ} \mathrm{C}$ with $58 \%-75 \%$ relative humidity. The eggs laid on the internal surface of the cups were collected and incubated until the emergence of the first instar larvae, which were subsequently reared on a modified European corn borer diet (Bio-Serv No. F9478B-M, without corn cob grits, Bio-Serv Co., Flemington, NJ, USA), supplemented with flour of the cowpea variety "Komcalle." Subsequent generations were regularly obtained after 24 days under the above mentioned conditions. For our experiment we used freshly laid eggs aged 0-12 h.

\section{Biopesticides}

A commercially available, emulsifiable neem preparation (Biophyto-Collines, Cotonou, Bénin) was diluted with tap water to obtain five concentrations for the bioassays:
$0.5 \% ; 0.62 \% ; 0.74 \% ; 0.87 \%$, and $1 \%$. Concentrations were made based on the recommendations of the International Institute of Tropical Agriculture (Benin) for the use of neem oil (1 $1 / \mathrm{ha})$ and those of the manufacturer ( $21 / h a)$. The final volume of each solution was $250 \mathrm{ml}$

The virus, MaviMNPV, was provided by the IITABenin biocontrol laboratory where it is routinely cultured on $M$. vitrata larvae from the original Taiwan strain. For this experiment we used the standard IITA recommended concentration of $1.6 \times 10^{11}$ Occluded Bodies $/ \mathrm{ml}(\mathrm{OB} / \mathrm{ml})$.

\section{Bioassays procedures}

Experiments were carried out using each of the above five neem solutions and MaviMNPV solution alone, a combination of each of the five neem solutions with MaviMNPV, and a tap water control. The numbers of eggs for each test solution were 6115 (neem oil), 2593 (MaviMNPV), and 5120 (MaviMNPV plus neem oil), and 2790 for the control.

To verify the specificity of MaviMNPV to M. vitrata eggs, a complementary study was carried out with the eggs of two other lepidopterans, Spodoptera frugiperda and Cirina butyrospermi. One concentration of $1.6 \times 10^{11} \mathrm{OB} / \mathrm{ml}$ virus MaviMNPV was used on of 956 and 979 eggs, respectively, plus a tap water control.

For each trial, eggs were dipped in the biopesticide test solution (or tap water control) for $3 \mathrm{~s}$ and allowed to air dry at room temperature. Subsequently, in each of the treatment conditions, one third of the eggs were washed (dipped in tap water for $3 \mathrm{~s}$ ) after $1 \mathrm{~h}$, one third were washed (dipped in tap water for $3 \mathrm{~s}$ ) after $12 \mathrm{~h}$, and the final third were not washed. Washing was meant to simulate possible likely effects of rainfall in cowpea fields. The eggs were then incubated in a room maintained at $24{ }^{\circ} \mathrm{C}$ with $58 \%-75 \%$ relative humidity until hatching. The eggs were monitored daily, and the number of hatched eggs were recorded. Emerging first instars larvae were also counted, and motionless larvae were considered dead.

\section{Data analyses}

Microsoft Excel was used for data capture, storage, exploration, and management. All analyses were carried out using SAS software version 9 (SAS Institute 2003). The ShapiroWilk test was used to test for normality of data collected, with subsequent Analyses of Variance (ANOVA) to test for significant differences among the treatments. When ANOVAs were significant, means were separated by the Student-NewmanKeuls test at the $5 \%$ level. 
Table 1 Effects of neem oil on the viability of $M$. vitrata eggs

\begin{tabular}{lllll}
\hline Neem oil Conc. $(\%)$ & \multicolumn{3}{l}{ Mean Egg Viability After Washing $(\% \pm \mathrm{SE})$} & \\
\cline { 2 - 5 } & Unwashed & $1 \mathrm{~h}$ & $12 \mathrm{~h}$ & \\
\hline Control: 0.0 & $77.28 \pm 10.3 \mathrm{Aa}$ & $85.31 \pm 7.8 \mathrm{Aa}$ & $88.09 \pm 4.2 \mathrm{Aa}$ & $(\mathrm{F}=0.60 \mathrm{P}<0.56)$ \\
0.5 & $22.06 \pm 7.5 \mathrm{Ab}$ & $29.61 \pm 2.8 \mathrm{Ab}$ & $21.57 \pm 4.3 \mathrm{Ab}$ & $(\mathrm{F}=0.91 \mathrm{P}<0.42)$ \\
0.62 & $13.07 \pm 5.5 \mathrm{Ab}$ & $27.36 \pm 5.7 \mathrm{Ab}$ & $13.69 \pm 3.2 \mathrm{Abc}$ & $(\mathrm{F}=2.71 \mathrm{P}<0.11)$ \\
0.75 & $9.37 \pm 3.2 \mathrm{Ab}$ & $14.20 \pm 3.1 \mathrm{Ac}$ & $13.33 \pm 2.4 \mathrm{Abc}$ & $(\mathrm{F}=0.91 \mathrm{P}<0.42)$ \\
0.87 & $7.25 \pm 2.5 \mathrm{Ab}$ & $11.38 \pm 2.7 \mathrm{Ac}$ & $7.34 \pm 2.9 \mathrm{Acd}$ & $(\mathrm{F}=0.92 \mathrm{P}<0.42)$ \\
1.00 & $5.72 \pm 2.1 \mathrm{Ab}$ & $9.94 \pm 2 \mathrm{Ac}$ & $3.59 \pm 0.9 \mathrm{Ad} \quad(\mathrm{F}=2.44 \mathrm{P}<0.12)$ \\
& $\mathrm{F}=7.93 ; \mathrm{P}<0.0002$ & $\mathrm{~F}=18.10 ; \mathrm{P}<0.0001$ & $\mathrm{~F}=12.96 ; \mathrm{P}<0.0001$ & \\
\end{tabular}

Means within a row followed by the same uppercase letter(s) and means within a column followed by the same lowercase letter(s) are not significantly different by SAS-SNK test $(\mathrm{P}<0.05)$

\section{Results}

Table 1 summarizes the significantly reduced $M$. vitrata egg viability from different test concentrations (Table 1). The rate of egg hatching decreased and was significantly different for increasing neem oil concentrations $(p<0.05)$ compared with the control. When eggs were washed with water either 1 or $12 \mathrm{~h}$ after being soaked in the neem solution, the biopesticide remained effective and significantly reduced the egg viability, with higher neem concentrations leading to higher egg mortality rate (Table 1). Egg washing time did not significantly $(p>0.05)$ affect the efficacy of the neem oil concentrations (Table 1).

Likewise, almost all of the different concentrations of neem oil resulted in $100 \%$ first instar larvae mortality, whether washed for $1 \mathrm{~h}, 12 \mathrm{~h}$, or not (Table 2). All of the larvae from the control survived.

Table 3 summarizes the efficacy of MaviMNPV on egg hatch rate and shows a significant difference $(\mathrm{p}<0.05)$ between washed, not washed, and control groups, with lower hatch rates in treatment groups compared to the control. A similar trend holds for hatched instar larvae mortality. In contrast, there was no significant difference $(p>0.05)$ in egg mortality between the control and MaviMNPV for the other tested lepidopterans (Table 4).

Overall, the combined MaviMNPV and neem oil solution significantly reduced egg viability and, in its highest concentrations, led to the lowest level of egg viability (Table 5). When eggs were washed with water either 1 or $12 \mathrm{~h}$ after being soaked in the combined MaviMNPV-neem solution, the biopesticide remained effective (Table 5). Similarly, when the eggs (washed or unwashed) hatched, all neonate larvae from the biopesticide treatment died while all of those from the control survived (Table 6).

\section{Discussion}

The present study confirms that when $M$. vitrata eggs were treated with neem oil, their viability is significantly reduced, similar to findings for several other insect species including Atherigona soccata Rondani (Zongo et al. 1993), Pieris brassicae (Hasan and Ansari 2011), Diatraea saccharalis (de Oliveira et al. 2013), Clavigralla gibbosa (Shukla and
Table 2 Effects of neem oil on M. vitrata hatched larvae mortality

\begin{tabular}{llll}
\hline Neem oil Conc. $(\%)$ & \multicolumn{2}{l}{ Mean Hatched Larvae Mortality After Washing (\%) } \\
\cline { 2 - 4 } & Unwashed & $1 \mathrm{~h}$ & $12 \mathrm{~h}$ \\
\hline Control: 0.0 & 0 & 0 & 0 \\
0.5 & 100 & 97.60 & 100 \\
0.62 & 100 & 97.63 & 100 \\
0.75 & 100 & 100 & 100 \\
0.87 & 100 & 100 & 100 \\
1.00 & 100 & 100 & 100 \\
\hline
\end{tabular}

ANOVA was not performed as all neem concentrations led to $100 \%$ mortality and the control did not have any mortality 
Table 3 Effects of MaviMNPV and washing on $M$. vitrata egg viability and hatched larvae mortality

\begin{tabular}{lll}
\hline Treatments & \multicolumn{2}{l}{ Mean $(\% \pm \mathrm{SE})$} \\
\cline { 2 - 3 } & Egg Viability & Hatched Larvae Mortality \\
\hline Control: Water & $86.74 \pm 2.5 \mathrm{a}$ & - \\
Unwashed Eggs & $15.95 \pm 8.5 \mathrm{~b}$ & $59.09 \pm 17.1 \mathrm{a}$ \\
Eggs Washed after 1 h & $21.74 \pm 9.3 \mathrm{~b}$ & $72.23 \pm 14.4 \mathrm{a}$ \\
Eggs Washed after 12 h & $17.29 \pm 9.8 \mathrm{~b}$ & $69.86 \pm 15.2 \mathrm{a}$ \\
& $\mathrm{F}=15.72 ; \mathrm{P}<0.0001$ & $\mathrm{~F}=0.20 ; \mathrm{P}<0.82$ \\
\hline
\end{tabular}

Means within a column followed by the same letter (s) are not significantly different by a SNK test $(\mathrm{P}<0.05)$
Kumar 2002), and stored product insects (Das 1987; Makanjuola 1989; Nukenine et al. 2011).

The ovicidal activity of neem oil could be due to its main chemical component, azadirachtin, as previously reported on Corcyra cephalonica (Pathak and Pandey 2011). On $M$. vitrata eggs, we recorded a $>90 \%$ mortality, which is similar to findings on A. soccata (Zongo et al. 1993) and much higher than reported on the sugarcane borer D. saccharalis (de Oliveira et al. 2013), a related Crambidae species. With crude extracts of $5 \%, 10 \%$ and $15 \%$ neem, a mortality range of $65-82 \%$ was reported on eggs of M. vitrata (Ekesi 2000). Other findings have indicated a limited effect of neem oil on the eggs of different insect pest species (Ahmad et al. 2015; Bruce et al. 2004; Marques et al. 2014; Seljåsen and Meadow 2006). Differences in the insecticidal effects of neem have been reported for several insect species because the contents of phytochemicals extracted from neem vary considerably due to biotic and abiotic factors and variations in product formulation (Gahukar 2014; Mouffok et al. 2008).

Our findings showed that neem oil remained highly effective even when the eggs were washed, indicating that the neem oil quickly penetrated the egg after treatment. In the case of head and body lice, an incubation time of only five minutes is sufficient to prohibit any larvae from hatching (Mehlhorn et al. 2011). In our case, the eggs were washed at $1 \mathrm{~h}$ and $12 \mathrm{~h}$ after being dipped in the neem solution, which likely gave enough time for the neem to enter the chorion. Specifically, neem enters eggs through aeropyles, tiny holes in the chorion, associated with the respiration of embryos (Pathak and Pandey 2011). It further induces chorion defects (Correia et al. 2013) and, as a consequence, the eggs dry up (Kaethner 1992). Interestingly, significant mortality occurred due to the residual activity on first instar larvae emergence from neem-treated eggs. Similar findings have been reported on Bemisia tabaci (Marques et al. 2014). Neem acts on the growth and molting of insect pests or as an anti-nutritional/anti-feedant (Blaney et al. 1990; Mouffok et al. 2008; Seljåsen and Meadow 2006). Neonate larvae may be killed by direct contact with the egg chorion when hatching or by consumption of neem present on the chorion.

When M. vitrata eggs were treated with MaviMNPV, the viability of the washed and the unwashed eggs also decreased significantly. However, MaviMNPV did not affect the egg hatchability of $C$. butyrospermi and S. frugiperda (see Table 4), suggesting its specificity to $M$. vitrata eggs. While MaviMNPV, like other baculoviruses, is essentially pathogenic to larvae, this is the first time a larval entomopathogenic virus has been reported to have direct effects on egg viability. While the mechanism behind this observation remains to be investigated, we can hypothesize that the ovicidal action of MaviMNPV may be physical, if viral bodies adhering to the egg obstruct the egg membrane and thus impede respiratory processes in the embryo. This might be peculiar to M. vitrata eggs, whose chorion has a slender appearance (Sharma et al. 1999) and might consequently be more fragile than the eggs of the two other lepidopterans tested in our study. Similar observations have been reported by Sato et al. (1980), who observed a strong binding of viral capsules to egg shells when
Table 4 Effect of MaviMNPV on the egg viability three lepidopterans

\begin{tabular}{llll}
\hline Virus Solution $\left(\times 10^{11} \mathrm{OB} / \mathrm{ml}\right)$ & \multicolumn{2}{l}{ Mean Eggs Hatched $(\% \pm \mathrm{SE})$} \\
\cline { 2 - 4 } & Maruca vitrata & Cirina butyrospermi & Spodoptera frugiperda \\
\hline 0 & $90.94 \pm 2.63 \mathrm{a}$ & $95.68 \pm 0.61 \mathrm{a}$ & $88.12 \pm 2.13 \mathrm{a}$ \\
1.6 & $16.88 \pm 0.69 \mathrm{~b}$ & $90.9 \pm 2,82 \mathrm{a}$ & $90.33 \pm 1.10 \mathrm{a}$ \\
& $\mathrm{F}=1515.03 ; P<0.0001$ & $\mathrm{~F}=0.46 ; P=0.54$ & $\mathrm{~F}=0.69 ; P=0.41$ \\
\hline
\end{tabular}

Means within a column followed by the same letter(s) are not significantly different by a SNK test $(\mathrm{P}<0.05)$ 
Table 5 Effect of the combination of neem oil and MaviMNPV on M. vitrata egg viability

\begin{tabular}{lllll}
\hline Neem Oil Conc. $(\%)+$ Virus $\left(\times 10^{\mathbf{1 1}} \mathrm{PIB} * / \mathrm{ml}\right.$ & \multicolumn{2}{l}{ Mean Egg Viability After Washing $(\% \pm \mathrm{SE})$} & \multicolumn{1}{l}{$12 \mathrm{~h}$} \\
\cline { 2 - 5 } & Unwashed & $1 \mathrm{~h}$ & $83.55 \pm 3.2 \mathrm{Aa}$ & $\mathrm{F}=1.79 ; \mathrm{P}<0.21$ \\
\hline Control: 0.0 & $83.82 \pm 4.1 \mathrm{Aa}$ & $73.67 \pm 5.4 \mathrm{Aa}$ & $19.87 \pm 1.6 \mathrm{Bb}$ & $\mathrm{F}=12.93 ; \mathrm{P}<0.0010$ \\
$0.5+1.6$ & $21.02 \pm 1.3 \mathrm{Bb}$ & $32.44 \pm 2.4 \mathrm{Ab}$ & $13.13 \pm 0.7 \mathrm{Bc}$ & $\mathrm{F}=15.02 ; \mathrm{P}<0.0005$ \\
$0.62+1.6$ & $12.62 \pm 0.6 \mathrm{Bc}$ & $17.91 \pm 0.4 \mathrm{Acb}$ & $6.82 \pm 1.4 \mathrm{Bd}$ & $\mathrm{F}=14.67 ; \mathrm{P}<0.0006$ \\
$0.75+1.6$ & $5.03 \pm 0.4 \mathrm{Bd}$ & $17.74 \pm 3.7 \mathrm{Acb}$ & $5.32 \pm 0.5 \mathrm{Bd}$ & $\mathrm{F}=7.27 ; \mathrm{P}<0.0085$ \\
$0.87+1.6$ & $4.11 \pm 0.4 \mathrm{Bd}$ & $15.29 \pm 5.9 \mathrm{Ac}$ & $2.43 \pm 0.3 \mathrm{Be} \quad$ & $\mathrm{F}=6.59 \mathrm{P}<0.011$ \\
$1.00+1.6$ & $2.10 \pm 0.9 \mathrm{Be}$ & $10.53 \pm 3.5 \mathrm{Ac}$ & $\mathrm{F}=139.18 \mathrm{P}<0.0001$ &
\end{tabular}

*PIB, polyhedron inclusion bodies. Means within a row followed by the same uppercase letter(s) and means within a column followed by the same lowercase letter(s) are not significantly different by a SNK test $(\mathrm{P}<0.05)$

the eggs of the tea tortrix, Homona magnanima Diaknoff, were dipped in a granulovirus solution.

Interestingly, in our study, MaviMNPV was also able to kill $59 \%-72 \%$ of the larvae that hatched from eggs dipped in the viral solution. An NPV virus was similarly found to inflict $93.6 \%$ mortality to larvae of Helicoverpa armigera hatching from eggs dipped in a viral solution immediately before hatching (Tuan et al. 1989). However, the maximum $72 \%$ larvae mortality recorded in our study was lower than that reported by Tamò et al. (2003) when directly spraying MaviMNPV onto M. vitrata larvae. The contact time between the virus and larvae could also explain mortality rate differences. Between four to six days were needed to achieve $100 \%$ larval mortality (Laleye 2007) whereas, in our case, mortality was recorded only four days after incubation. The hatching larvae of M. vitrata may acquire MaviMNPV by feeding on the egg chorion during emergence and ingesting the virus as reported on an unknown insect species (Ibarra and del Rincón Castro 2001), Spodoptera exigua (Yu and Brown 1997), Heliothis virescens (Jackson et al. 1992), and H. armigera (Tuan et al. 1989).
The combined application of MaviMNPV with neem oil led to a significantly higher egg mortality than those components separately. As indicated above, while egg mortality is caused by neem's ovicidal action, neem may also obstruct egg membranes and limit respiration (Schmutterer 1990). The membrane obstruction by both the neem and MaviMNPV in addition to neem's chemical actions may explain the higher ovicidal activities of the combined products. Likewise, the combination of neem and MaviMNPV led to a higher larval mortality rate. This confirms previously noted synergetic effects of neem and MaviMNPV on M. vitrata larvae (Sokame et al. 2015). Similar trends were also observed for Spodoptera litura Fabricius (Lepidoptera: Noctuidae) using a combination of azadirachtin and SpltNPV (Nathan and Kalaivani 2006).

Overall, our findings suggest that a compound solution of neem and MaviMNPV could be sprayed early in cowpea when $M$. vitrata moths first appear in the field to coincide with egg laying and to provide a more efficient control. This is similar to controlling Chilo suppressallis in rice using early NPV applications (Zhai and Chai 2013).
Table 6 Effect of the combination of neem oil and MaviMNPV on $M$. vitrata hatched larvae

\begin{tabular}{llll}
\hline Neem Oil Conc. $(\%)+$ Virus $\left(\times 10^{\mathbf{1 1}} \mathrm{PIB} * \mathrm{ml}\right.$ & \multicolumn{2}{l}{ Mean Hatched Larvae Mortality After Washing $(\%)$} \\
\cline { 2 - 4 } & Unwashed & $1 \mathrm{~h}$ & $12 \mathrm{~h}$ \\
\hline Control: 0.0 & 0 & 0 & 0 \\
$0.5+1.6$ & 100 & 91.91 & 100 \\
$0.62+1.6$ & 100 & 96.42 & 100 \\
$0.75+1.6$ & 100 & 97.89 & 100 \\
$0.87+1.6$ & 100 & 98.57 & 100 \\
$1.00+1.6$ & 100 & 100 & 100 \\
\hline
\end{tabular}

*PIB, polyhedron inclusion bodies. ANOVA was not performed as similar numbers were recorded for all five treatments and zero mortality on the control 
Acknowledgments This project has been made possible through support provided by the Legumes Innovation Lab, formerly known as the Dry Grains Pulses Collaborative Research Support Program (CRSP), by the Bureau for Economic Growth, Agriculture, and Trade, US Agency for International Development, under the terms of Grant No. EDH-A-00-0700005. We also thank Théodore Ouédraogo and Simon Tarpidiga of Institut de l'Environnement et de Recherches Agricoles (INERA), Station of Kamboinsé, Burkina Faso, for their technical assistance in data collection.

\section{Compliance with ethical standards}

Conflict of interest The authors declare that they have no conflict of interest.

Open Access This article is licensed under a Creative Commons Attribution 4.0 International License, which permits use, sharing, adaptation, distribution and reproduction in any medium or format, as long as you give appropriate credit to the original author(s) and the source, provide a link to the Creative Commons licence, and indicate if changes were made. The images or other third party material in this article are included in the article's Creative Commons licence, unless indicated otherwise in a credit line to the material. If material is not included in the article's Creative Commons licence and your intended use is not permitted by statutory regulation or exceeds the permitted use, you will need to obtain permission directly from the copyright holder. To view a copy of this licence, visit http://creativecommons.org/licenses/by/4.0/.

\section{References}

Ahmad S, Ansari MS, Muslim M (2015) Toxic effects of neem based insecticides on the fitness of Helicoverpa armigera (Hübner). Crop Prot 68:72-78. https://doi.org/10.1016/j.cropro.2014.11.003

Amatobi C (1995) Insecticide application for economic production of cowpea grains in the northern Sudan savanna of Nigeria. Int J Pest Manag 41(1):14-18. https://doi.org/10.1080/09670879509371914

Atachi P, Sourokou B (1989) Use of Decis ${ }^{\circledR}$ and Systoate ${ }^{\circledR}$ for the control of Maruca testulalis (Geyer) in cowpea. Int J Trop Insect Sci 10(3):373-381. https://doi.org/10.1017/S1742758400003635

Ba MN, Margam VM, Binso-Dabire CL, Sanon A, McNeil JN, Murdock LL, Pittendrigh BR (2009) Seasonal and regional distribution of the cowpea pod borer Maruca vitrata (Lepidoptera: Crambidae) in Burkina Faso. Int J Trop Insect Sci 29(3):109-113. https://doi.org/ 10.1017/S174275840999021X

Blaney W, Simmonds M, Ley S, Anderson J, Toogood P (1990) Antifeedant effects of azadirachtin and structurally related compounds on lepidopterous larvae. Entomologia Experimentalis et Applicata 55(2):149-160. https://doi.org/10.1111/j.1570-7458. 1990.tb01358.x

Bottenberg H, Singh B (1996) Effect of neem leaf extract applied using the 'broom'method, on cowpea pests and yield. Int J Pest Manag 42(3):207-209. https://doi.org/10.1080/09670879609371995

Bruce YA, Gounou S, Chabi-Olaye A, Smith H, Schulthess F (2004) The effect of neem (Azadirachta indica A. Juss) oil on oviposition, development and reproductive potentials of Sesamia calamistis Hampson (Lepidoptera: Noctuidae) and Eldana saccharina Walker (Lepidoptera: Pyralidae). Agric For Entomol 6(3):223232. https://doi.org/10.1111/j.1461-9555.2004.00218.x

Correia AA, Wanderley-Teixeira V, Teixeira ÁA, Oliveira JV, Gonçalves GG, Cavalcanti MG et al (2013) Microscopic analysis of Spodoptera frugiperda (Lepidoptera: Noctuidae) embryonic development before and after treatment with azadirachtin, lufenuron, and deltamethrin. J Econ Entomol 106(2):747-755. https://doi.org/ 10.1603/EC12158

Das G (1987) Efficacy of neem oil on the egg grub mortality of Callosobruchus chinensis Linn (Bruchidae: Coleoptera). Tropical Grain Legumes Bulletin 34:14-15

de Oliveira H, Santana A, Antigo M (2013) Insecticide activity of physic nut (Jatropha curcas 1.) oil and neem (Azadirachta indica A. Juss.) oil on eggs of Diatraea saccharalis (Fabr.)(Lepidoptera: Crambidae). Arquivos do Instituto Biológico 80(2):229-232. https://doi.org/10.1590/S1808-16572013000200013

Drabo E (2014) Efficacité des biopesticides sur les Thrips des fleurs et Maruca vitrata, ravageurs du niébé en culture. (Mémoire de fin de cycle pour l'obtention de la licence professionnelle), Université de Ouagadougou, Ouagadougou, Burkina Faso

Ekesi S (2000) Effect of volatiles and crude extracts of different plant materials on egg viability of Maruca vitrata and Clavigralla tomentosicollis. Phytoparasitica 28(4):305-310. https://doi.org/10. 1007/BF02981825

Gahukar R (2014) Factors affecting content and bioefficacy of neem (Azadirachta indica A. Juss.) phytochemicals used in agricultural pest control: a review. Crop Prot 62:93-99. https://doi.org/10.1016/ j.cropro.2014.04.014

Hasan F, Ansari MS (2011) Toxic effects of neem-based insecticides on Pieris brassicae (Linn.). Crop Prot 30(4):502-507. https://doi.org/ 10.1016/j.cropro.2010.11.029

Ibarra JE, del Rincón Castro MC (2001) Capacidad insecticida de los baculovirus. In: Caballero P, Williams T, López Ferber M (eds) Los baculovirus y sus aplicaciones como bioinsecticidas en el control biológico de plagas. PHYTOMA-Universidad Pública de Navarra, Pamplona, pp 203-224

Jackai L, Oyediran I (1991) The potential of neem Azadirachta indica A. Juss for controlling post-flowering pests of cowpea, Vigna unguiculata Walp - I. The pod borer, Maruca testulalis. Int J Pest Manag 12(1-3):103-109. https://doi.org/10.1017/ S1742758400020580

Jackai L, Inang E, Nwobi P (1992) The potential for controlling postflowering pests of cowpea, Vigna unguiculata Walp. using neem, Azadirachta indica A. Juss. Int J Trop Insect Sci 38(1):56-60. https://doi.org/10.1080/09670879209371646

Jackson MD, Brown G, Nordin G, Johnson D (1992) Autodissemination of a baculovirus for management of tobacco budworms (Lepidoptera: Noctuidae) on tobacco. J Econ Entomol 85(3):710 719. https://doi.org/10.1093/jee/85.3.710

Kadri A, Moussa OZ, Yacouba AS, Abdou KH, Karimoune L (2013) Gestion intégrée de Maruca vitrata (Fabricus, 1787) et Megalurothrips sjostedti (Trybom, 1908), deux insectes ravageurs majeurs du niébé au Niger. Int J Biol Chem Sci 7(6):2549-2557. https://doi.org/10.4314/ijbcs.v7i6.29

Kaethner M (1992) Fitness reduction and mortality effects of neem-based pesticides on the Colorado potato beetle Leptinotarsa decemlineata Say (Col., Chrysomelidae). J Appl Entomol 113(1-5):456-465. https://doi.org/10.1111/j.1439-0418.1992.tb00689.x

Laleye DW (2007) Interaction de baculovirus MaviNPV et du parasitoïde (Apanteles taragamae (Viereck)) (Hymenoptera : Braconidae) pour le contrôle de Maruca vitrata Fabricius (Lepidoptera : Pyralidae). (Mémoire pour l'obtention du diplôme d'Ingénieur Agronome, option Sciences et Techniques de Production Végétale), Université d'Abomey-Calavi, Cotonou, Benin

Lee S-T, Srinivasan R, Wu Y-J, Talekar N (2007) Occurrence and characterization of a nucleopolyhedrovirus from Maruca vitrata (Lepidoptera, Pyralidae) isolated in Taiwan. BioControl 52(6): 801-819. https://doi.org/10.1007/s10526-006-9049-x

Makanjuola W (1989) Evaluation of extracts of neem (Azadirachta indica A. Juss) for the control of some stored product pests. J 
Stored Prod Res 25(4):231-237. https://doi.org/10.1016/0022474X(89)90029-5

Marques M d A, Quintela ED, Mascarin GM, Fernandes PM, Arthurs SP (2014) Management of Bemisia tabaci biotype B with botanical and mineral oils. Crop Prot 66:127-132. https://doi.org/10.1016/j. cropro.2014.09.006

Martinez SS (2002) Composiçào do nim. In: Martinez SS (ed) O nim (Azadirachta indica) natureza, usos multiplos, produçào. Instituto agronômico do Paraná (IAPAR), Londrina, pp 23-30

Mehlhorn H, Abdel-Ghaffar F, Al-Rasheid KA, Schmidt J, Semmler M (2011) Ovicidal effects of a neem seed extract preparation on eggs of body and head lice. Parasitol Res 109(5):1299-1302. https://doi.org/ 10.1007/s00436-011-2374-8

Mouffok B, Raffy E, Urruty N, Zicola J (2008) Le neem, un insecticide biologique efficace. Université Paul Sabatier IUT, Département Génie Biologie, Toulouse

Nathan SS, Kalaivani K (2006) Combined effects of azadirachtin and nucleopolyhedrovirus (SpltNPV) on Spodoptera litura Fabricius (Lepidoptera: Noctuidae) larvae. Biol Control 39(1):96-104. https://doi.org/10.1016/j.biocontrol.2006.06.013

Nukenine EN, Tchiegang C, Mekouo AAT, Tofel KH, Adarkwah C, Obeng-Ofori D, Adler C (2011) Efficacy of Calneem derived from Ghanaian neem seeds and seed oils from two locations in Cameroon against Sitophilus zeamais (Coleoptera: Curculionidae) on maize. Int J Trop Insect Sci 31(4):225-234. https://doi.org/10.1017/ S1742758411000348

Ouédraogo T (2013) Gestion intégrée des insectes ravageurs du niébé en culture dans les régions centre du Burkina Faso: Combinaison de la résistance variétale aux punaises avec des traitements à base de neem et du cipovirus contre Maruca vitrata Fab. (Mémoire de fin de cycle pour l'obtention de la licence professionnelle), Université de Ouagadougou, Ouagadougou, Burkina Faso

Pathak P, Pandey S (2011) Impact of combined action of Neem and Eucalyptus oil volatiles on different stages of Corcyra cephalonica (Lepidoptera: Pyralidae). J Appl \& Nat Sci 3(2):247-252. https:// doi.org/10.31018/jans.v3i2.190

Pimentel D, Acquay H, Biltonen M, Rice P, Silva M, Nelson J et al (1992) Environmental and economic costs of pesticide use. BioScience 42(10):750-760

SAS Institute (2003) Version 9 for windows. SAS Institute, North Carolina State University, Raleigh

Sato T, Oho N, Kodomari S (1980) A granulosis virus of the tea tortrix, Homona magnanima Diaknoff (Lepidoptera: Tortricidae): its pathogenicity and mass-production method. Appl Entomol Zool 15(4): 409-415. https://doi.org/10.1303/aez.15.409

Schmutterer H (1990) Properties and potential of natural pesticides from the neem tree, Azadirachta indica. Annu Rev Entomol 35(1):271297. https://doi.org/10.1146/annurev.en.35.010190.001415

Seljåsen R, Meadow R (2006) Effects of neem on oviposition and egg and larval development of Mamestra brassicae L: dose response, residual activity, repellent effect and systemic activity in cabbage plants. Crop Prot 25(4):338-345. https://doi.org/10.1016/j.cropro. 2005.05.007

Sharma HC, Saxena KB, Bhagwat VR (1999) The legume pod borer, Maruca vitrata: bionomics and management. (Information Bulletin no. 55). Patancheru, India: International Crops Research Institute for the Semi-arid Tropics (ICRISAT)

Shukla A, Kumar A (2002) Ovicidal properties of some plant oils against pigeonpea pod sucking bug, Clavigralla gibbosa Spinola (Coreidae: Hemiptera). Plant Prot Bull 54(1/2):15-16

Sokame BM, Tounou AK, Datinon B, Dannon EA, Agboton C, Srinivasan R, Tamò M (2015) Combined activity of Maruca vitrata multi-nucleopolyhedrovirus, MaviMNPV, and oil from neem, Azadirachta indica Juss and Jatropha curcas L., for the control of cowpea pests. Crop Prot 72:150-157. https://doi.org/10.1016/j. cropro.2015.03.016

Tamò M, Ekesi S, Maniania NK, Cherry A (2003) Biological control: a non-obvious component of IPM for cowpea. In: Neuenschwander P, Borgemeister C, Langewald J (eds) Biological control in IPM systems in Africa. CAB International, Wallingford, pp 295-309

Tamò M, Srinivasan R, Dannon E, Agboton C, Datinon B, Dabire C, Pittendrigh BRR (2012) Biological control: a major component for the long-term cowpea pest management strategy. Paper presented at the enhancing cowpea value chains through research advances. Proceedings of the 5th World Cowpea Research Conference, Saly, Senegal

Tan X, Sabbagh G, Cuperus G, Gregory M (1996) Evaluating potential environmental impact of insecticide applications in a boll weevil eradication program. J Am Water Resour Assoc 32(5):1027-1037. https://doi.org/10.1111/j.1752-1688.1996.tb04071.x

Tanzubil P (2000) Field evaluation of neem (Azadirachta indica) extracts for control of insect pests of cowpea in Northern Ghana. J Trop For Prod 6(2):165-172

Traoré F, Dabire-Binso CL, Ba NM, Sanon A, Pittendrigh BR (2013) Feeding preferences of the legume pod borer Maruca vitrata (Lepidoptera: Crambidae) larvae and suitability of different flower parts for larval development. Int J Trop Insect Sci 33(02):107-113. https://doi.org/10.1017/S1742758413000088

Tuan S-J, Tang L-C, HOU RF-N (1989) Control of Heliothis armigera in maize with a nuclear polyhedrosis virus. Appl Entomol Zool 24(2): 186-192. https://doi.org/10.1303/aez.24.186

Valle Pinheiro P, Dias Quintela E (2010) Neem oil antifeedant and insecticidal effects on Oebalus poecilus (Hemiptera: Pentatomidae) males and females. Pesquisa Agropecuária Tropical 40(4):394-400

Yu Z, Brown G (1997) Autodissemination of a beet armyworm (Lepidoptera: Noctuidae) baculovirus under laboratory conditions. J Econ Entomol 90(5):1187-1194. https://doi.org/10.1093/jee/90.5. 1187

Zhai HW, Chai YY (2013) Effect of Mamestra brassicae nuclear polyhedrosis virus suspending agent on Chilo suppressalis in rice. North Rice 43(2):64-65

Zongo J, Vincent C, Stewart R (1993) Effects of neem seed kernel extracts on egg and larval survival of the sorghum shoot fly, Atherigona soccata Rondani (Dipt., Muscidae). J Appl Entomol 115(1-5):363-369

Publisher's note Springer Nature remains neutral with regard to jurisdictional claims in published maps and institutional affiliations. 